\title{
FANON, THE FRENCH LIBERAL LEFT AND THE COLONIAL CONSENSUS
}

\section{AZZEDINE HADDOUR}

The Algerian revolution, as David Macey astutely remarks, marked the high tide of ThirdWorldism, with Fanon becoming the spokesman par excellence of this new movement for a generation of intellectuals who were disillusioned with the orthodox left as it was represented by the Parti communiste français (PCF). ${ }^{1}$ The liberal left, however, castigated his brand of Third-Worldism for advocating a humanism of violence. ${ }^{2}$ So how are we to read his commitment to defend the values of the free world by joining the dissidence in the Second World War? Are we, following the journalist Gilbert Comte's scathing review of Les Damnés de la terre, to see in it a 'pitiless hostility that screams in the mad darkness' and that smacks of Hitler's Mein Kampf? ${ }^{3}$ How are we to interpret his take on Marxism in conjunction with the PCF's colonial policies that helped the ultras institute the raison d'état in the Algerian war? Is it contradictory to present Fanon as an intellectual following in the footsteps of Zola and the Dreyfusards who stood resolutely against this very raison d'état? My aim in this article is to nuance this critique of Fanon by reinserting the issue of race into the Marxist debate on the colonial question. I shall underscore the fact that Fanon consistently defended the Republican tradition and I shall seek to shed some light on a murky period in French history when nationalism cemented a consensus between left and right, a consensus which gave rise to colonial fascism. I shall focus first on the prevalent Marxist interpretation of Fanon and attempt to situate it in relation to the PCF's 'assimilationist' politics which shaped such consensus and ultimately offered fertile ground for the emergence of colonial fascism in the 1950s. I shall then examine Fanon's journalistic writings to show that he upheld the Republican - and more specifically Dreyfusard - tradition which was jettisoned by the left at 
the height of the Algerian crisis. Finally, I shall engage with Jean-François Lyotard's analysis in La Guerre des Algériens to demonstrate how nationalism came to underlie racial antagonism. Fanon's reworking of Marxist theory helps us understand how the colonial issue was overshadowed by the internationalist rhetoric of the Comintern and the nationalist discourse of the PCF's anti-fascist front. In this article, I shall seek to demonstrate that Les Damnés de la terre is, in effect, an anthem that draws its significance from the Internationale, but one that rethinks the Marxist-Leninist doctrine that acted in complicity with colonialism.

\section{The Marxist interpretation of Fanon}

If colonialism brought whites and blacks into a partnership of uneven reciprocity, ${ }^{4}$ it was a relationship that proved to be doubly alienating for Fanon. In Peau noire, masques blancs, he subscribes to a cultural materialist approach which conceives of the issue of racism as a construct determined by economic conditions. He is adamant that the inferiority complex is engendered by a double process: the economic inferiority of the colonized people is coupled with the internalization - or what he calls the 'épidermisation' - of such inferiority. ${ }^{5}$ In Les Damnés de la terre, he comes to recognize the limits of Marxist analysis in accounting for racism and colonialism: 'Les analyses marxistes doivent être toujours légèrement distendues chaque fois qu'on aborde le problème colonial. Il n'y a pas jusqu'au concept de société précapitaliste, bien étudié par Marx, qui ne demanderait ici à être repensé. ${ }^{6} \mathrm{He}$ cautions against orthodox Marxist theory which considers the bourgeois phase as a necessary step towards the advent of classless society. By reversing the roles Marx assigned to the proletariat and the lumpenproletariat, Fanon radically subverts Marxist theory. In his conception of the revolution, the proletariat is not revolutionary but rather constitutes 'le noyau du peuple colonisé le plus choyé par le régime colonial' $;^{7}$ the lumpenproletariat is not a reactionary class but rather is the most revolutionary. The bourgeois phase in the post-independence state, 
Fanon argues, is a useless phase.

Focussing on the pitfalls of national culture, Nguyen Nghe identifies in Fanon's revolutionary politics vestiges of subjectivism drawn from the Sartrean existential phenomenology that was fashionable at the time, and he chides him for promoting the mythology of the peasantry's 'redemptive' violence as a panacea against the ills of colonialism. ${ }^{8}$ Unlike Fanon, Nghe argues that the national bourgeoisie did not represent a useless phase in the process of decolonization. ${ }^{9}$ Fanon's revolutionary politics, he claims, misleads his readers into believing that the peasantry alone expresses the spontaneity of the masses, whereas the mobilization of the peasantry would not have been possible without the political organization provided by the national bourgeoisie. ${ }^{10} \mathrm{He}$ criticizes Fanon for overlooking the significance of class alliance in the revolution, an alliance which was crucial in marshalling Algerian nationalism; he also criticizes him for confusing the proletariat with the petty bourgeoisie. ${ }^{11}$ In Nghe's view, Fanon, whilst highlighting the privileges of the working class in comparison to the impoverished peasantry, fails to comprehend that the former was better positioned in relation to the mechanisms of power: its privileges enabled it to grasp the extent of colonial exploitation and to instigate resistance. ${ }^{12}$ Put simply, according to Nghe, Fanon seems oblivious to the historical totality of the Algerian revolution which had its bases in the city and to the fact that the peasants who engaged in armed struggle received their political education from bourgeois intellectuals who lived in the city. ${ }^{13}$ In other words, the interaction between the city and the countryside was crucial in determining the history of the revolutionary movement. For Nghe, then, the working class in Algeria's colonial cities and the immigrants in mainland France were not disinterested bystanders but played a crucial role. ${ }^{14}$ He therefore criticizes Fanon for waxing lyrical about the peasantry and idealizing its armed resistance. Nghe effectively turns Fanon's argument on its head: without the nationalist leaders, the peasants who were influenced by the maraboutic religious leaders in the pay of 
the colonial administration would have been incapable of harnessing the revolution. ${ }^{15}$

Nghe also calls into question Fanon's international politics, dismissing his call to the ex-colonized nations to abandon the chimera of following the path taken by Europe. ${ }^{16}$ More specifically, he criticizes Fanon for his conception of a new humanism to be founded in the Third World and for his politics of non-alignment. Nghe contends that the Third World, in the rhetoric of Fanon, was vacuous and could not provide the foundations for political or historical development. He pours scorn on Fanon for sitting on the ideological fence of ThirdWorld neutrality: it was not a question of choosing between East and West, or better still between the Third World and Europe, but between two differing conceptions of the world, namely capitalism and communism. As persuasive and as memorable as this kind of critique might be, it nevertheless glosses over the specificities of the context out of which Fanon intervened. To have a better understanding of his Third-Worldism and his ideological neutrality, I want now to consider Nghe's critique in the light of the PCF's problematic political stance vis-à-vis the colonial question.

\section{'Assimilationist' politics and colonial fascism}

In the early 1930s, the Comintern altered its strategy on the colonial question by abandoning the class-against-class policy in favour of an anti-fascist front. After the Franco-Soviet Pact, the PCF underwent a process of nationalization, renouncing its internationalist stance all the better to focus on French domestic affairs. In order to thwart the rise of fascism, Maurice Thorez joined the Front populaire and sought subsequently to extend the alliance with the right in 1939, well after Blum's centre-left coalition government collapsed. ${ }^{17}$ There was, however, a perceptible shift in the colonial policies of the PCF: the anti-fascist front ostensibly eclipsed the colonial question and Thorez jettisoned the anticolonial policies which the party previously advocated in the Riff War. This change of strategy exacerbated the close 
relationship that the Etoile nord-africaine (ENA) had established with the PCF in the 1920s. In June 1936, Blum banned the ENA from attending the Congrès musulman algérien. After its dissolution in 1937, the party re-emerged as the Parti du peuple algérien (PPA), championing decolonization. The PPA opposed not only the PCF but also the 'élus' and Oulemas for supporting the Blum-Viollette Bill in 1937. The failure of the latter raised concerns that Algerian nationalism might be hijacked by fascism. In February 1939, just a few months before the outbreak of the Second World War, Thorez visited Algeria. On 11 February, he delivered a speech in Algiers defining the party's position with regards to the colonial question and the issue of fascism. ${ }^{18}$

Thorez's representation of Algeria as a ‘nation-in-formation' chimed with Gabriel Audisio's and Albert Camus's assimilationist rhetoric refusing the dichotomous language of colonialism and ran counter to the celebration of the génie helléno-latin in Louis Bertrand's novel Le Sang des races (1899). ${ }^{19}$ If, in the symbiosis of cultures, Bertrand maintained the supremacy of the Latin conquerors, in Le Sel de la mer, by contrast, Audisio denounced Bertrand's 'Afrique latine' as an instrument of coloniality, proposing instead a 'Mediterranean humanism' transcending racial and nationalistic chauvinism, contrasting the fascistic ideology of totalitarianism with the 'sens vivant de la communaute' ${ }^{20}$ Under the auspices of the PCF and two days after Thorez addressed the party - Camus made his presentation to the Maison de la culture in Algiers. Taking his cue from Thorez and Audisio, he differentiated his Mediterranean from Bertrand's 'Méditerranée abstraite et conventionnelle', the Mediterranean '[du] plagiat humain', characterized by its 'génie militaire' and its 'image académique'. ${ }^{21}$ Bertrand was one of the intellectuals who supported Mussolini's colonial endeavour in Ethiopia, and Camus denounced the proponents of Latinity for their pro-fascistic tendencies. ${ }^{22}$ The Mediterranean was an important strategic site in the fight against fascism.

Thorez's intervention in Algeria - his pronouncements hailing Algeria as a nation-in- 
formation, as a melting pot in which twenty races merged to form one nationhood - was a rebuttal of Bertrand's racist discourse. In his speech, supplanting the notion of race with that of nationality, Thorez affirmed:

Nous, communistes, nous ne connaissons pas les races. Nous ne voulons connaître que les peuples. [...] Il y a la nation algérienne qui se constitue historiquement et dont l'évolution peut être facilitée, aidée par l'effort de la République française. [...] Il y a une nation algérienne qui se constitue, elle aussi, dans le mélange de vingt races. ${ }^{23}$

At the PCF's ninth congress, held in Arles on 29 December 1937, Thorez had reiterated Lenin's idea that 'le droit au divorce ne signifiait pas l'obligation de divorcer'. ${ }^{24} \mathrm{He}$ had warned that the anti-colonialist agenda could only help fascism promote its movement in the colonies:

Si la question décisive du moment, c'est la lutte victorieuse contre le fascisme, l'intérêt des peuples coloniaux est dans leur union avec le peuple de France et non dans une attitude qui pourrait favoriser les entreprises du fascisme et placer, par exemple, l'Algérie, la Tunisie et le Maroc, sous le joug de Mussolini ou d'Hitler, ou de faire de l'Indochine une base d'opérations pour le Japon militariste. ${ }^{25}$

On 11 February 1939, he cautioned the nationalists that 'la victoire du fascisme n'amènerait nullement leur libération et ne solutionnerait pas le problème de leur émancipation' ${ }^{26} \mathrm{He}$ stressed the urgent need to rally behind the anti-fascist front and defend the Republic. Referring to the Blum-Viollette Bill, Thorez was behind the times as he proposed outmoded measures - 'ce minimum encore bien modeste [...] doit être voté, et le libre exercice de leur culte garanti aux Musulmans, ${ }^{27}$ - which had already been rejected. His speech could be interpreted as an attempt to re-mobilize the disenchanted Algerian nationalist movement. However, after the rejection of the bill, the brand of 'Algerian nationalism' which he reaffirmed in order to keep the 'élus' and Oulemas within the coalition was anachronistically assimilationist.

After the Second World War, France sought to reassert her sovereignty over her overseas territories. At the Brazzaville conference in 1944, General de Gaulle presided over the re-organization of the French Empire by initiating political reforms to ensure that the 
independence of the colonies would develop within the framework of the French Union.

Significantly, de Gaulle was not the only political figure to believe that the grandeur of France depended on the maintenance of the Empire. Various socialist leaders shared this belief: Blum in 1946 with the outbreak of the hostilities in Indochina, followed by Mollet and Lacoste in 1956-7 at the height of the Algerian war. There was a consensus in the post-war period which curtailed parliamentary divisions on the colonial issue and created a community of shared interests which worked to maintain France's hold over her Empire. ${ }^{28}$ As Tony Smith argues, 'there is ample evidence that the major concerns of the SFIO [Section française de l'Internationale ouvrière] bound them to rather than divided them from the parties to their right' ${ }^{29}$ Blum's stance against the anticolonial policies of the PCF at the Congrès de Tours in 1920 and his policies as well as those of his successors - Ramadier in 1947 and Mollet in 1956 - are a case in point. ${ }^{30}$ The issue of decolonization in Indochina and Algeria did not exacerbate the political instability of the French political system; on the contrary, it created a consensus. The Algerian war consolidated such consensus - and Molletism came to epitomize it. Commenting on Blum's and Ramadier's policies in the Indochinese war in 1946-7 and on Mollet's Algerian policies in 1956-7, Smith contends that 'it was unity, resolution and action which at certain critical points were the hallmarks of the regime', adding: 'What marked these crucial periods of socialist leadership was not so much the fatal logic of a political system as the fatal logic of a colonialist perspective.' ${ }^{31}$

If we dwell on the Mollet government, it is because its policies shaped Fanon's views vis-à-vis the colonial question and the liberal left. The socialist Mollet campaigned in the legislative elections of January 1956 to form a coalition government on the basis of a political platform to negotiate with the Front de libération nationale (FLN) and restore peace.

However, once he was elected to office and after the infamous 'journée des tomates', ${ }^{32}$ Mollet pursued a policy of pacification by deploying scores of conscripted soldiers to quell the FLN 
rebellion. He replaced General Catroux with Robert Lacoste as Governor General. Lacoste's attempt to bring about social and political change was thwarted by French settlers. Frightened by the ultras who were calling for his resignation, the socialist Lacoste, in an attempt to show that France still maintained its control over Algeria, implemented repressive measures which triggered the Battle of Algiers. On 12 March 1956, Mollet (with the help of the communists) passed the Special Powers Act implementing a programme of actions, which bypassed the National Assembly and ultimately ceded power to the military - a course of action that was of dubious legality under French law and that went against the grain of the Republican tradition. Moreover, to stifle the support of Nasser's Egypt for the FLN, he opened another front by waging the Suez War in October 1956. The $10^{\text {th }}$ Parachute Division, led by Massu, was deployed first to Egypt and then, at the end of the Suez hostilities, to Algiers. On 7 January 1957, the civilian authorities relinquished power to the military and Massu was given special powers to crush the FLN organization. In sum, Molletism was a resolute stance to keep Algeria French, hypostatizing the colonial consensus. It was in protest against the Mollet government that Fanon resigned his post in Blida. In his letter of resignation, written to the Resident Minister Lacoste in late 1956, Fanon bemoans the systematic dehumanization of the colonized Algerians. ${ }^{33}$ It is no coincidence that Aimé Césaire resigned from the PCF at about the same time as Fanon because of Mollet's retrograde colonial policies.

\section{Journalism and the Republican tradition}

Fanon's critique of the liberal left in his journalistic writings targets the cosy relationship that French communists had with the ultras who worked to maintain the colonial status quo. His article 'La Minorité européenne d'Algérie', published in Les Temps modernes in May-June 1959 , needs to be considered alongside the series of three articles he had published in December 1957 in El Moudjahid under the title 'Les Intellectuels et les démocrates français 
devant la révolution algérienne'. There are certainly inconsistencies in Fanon's assessment of the political position of the French liberal left, but these were not the outcome of his brand of nationalism; rather, they were determined by the political context out of which he intervened. To understand the significance of 'La Minorité européenne d'Algérie', it is worth comparing the Algerian liberal left, which helped recruit him to the Algerian cause, with the French liberal left, led by the socialist Guy Mollet or the liberal Maurice Bourgès-Maunoury, who worked to maintain French colonial presence in Algeria.

Whereas in 'Les Intellectuels et les démocrates français devant la révolution algérienne' Fanon tars the liberal left with the same brush because of their lack of commitment to the Algerian cause, in 'La Minorité européenne d'Algérie' he is careful not to lump all the Europeans together. The European minority in Algeria, he contends, never constituted a monolithic colonialist block. ${ }^{34}$ The leaders of the Mouvement pour le triomphe des libertés démocratiques (MTLD) and the Union démocratique du manifeste algérien (UDMA) established contact with the European minority precisely because they grasped this political fact and understood the important role that liberal Europeans could play in Algeria's decolonization. Fanon describes the relationship these liberal Europeans had with their Muslim counterparts - men and women alike - as an association of joint endeavour for the establishment of a democratic Algeria. ${ }^{35}$ He makes clear that this relationship was different from the so-called Franco-Muslim fraternization which the colonial administration promoted as part of the psychological warfare to break the revolutionary movement.

Unlike their French counterparts, the French Algerians could not advocate openly the principles of democracy. They could not militate outside the Communist Party which held an assimilationist stance and which acted in complicity with the colonial administration. ${ }^{36}$ In 'Les Intellectuels et les démocrates français devant la révolution algérienne', Fanon pits the French liberal left against its Algerian counterpart: in cahoots with the colonial 
administration, the French liberal left lent their support to the Mollet government, whereas the Algerian liberal left - albeit muzzled, persecuted and tortured by the administration - were unequivocal in their support for the Algerian people. Fanon notes that the French government, led by the socialist Mollet and the liberal Bourgès-Maunoury, was consistent in its policy of pacification. He remarks ironically:

Depuis 1956, la guerre d'Algérie est acceptée par la nation. La France veut la guerre, diront explicitement M. Guy Mollet et M. Bourgès-Maunoury; et le peuple parisien, le 14 juillet 1957, exprimera aux parachutistes tortionnaires de Massu la grande reconnaissance de la patrie. Les libéraux abandonnent la lutte à cette phase. L'accusation de trahison qui guette les adversaires de la guerre d'Algérie devient une arme redoutable entre les mains du gouvernement français. Ainsi a-t-on pu voir au début de l'année 1957 un grand nombre démocrates se taire ou être fauchés par la vague revancharde et élaborer un patriotisme élémentaire mal structuré, hanté par le racisme, violent, totalitaire, somme toute fasciste. ${ }^{37}$

The Mollet government fell on 21 May 1957; the liberal Bourgès-Maunoury replaced Mollet on 25 June, but the change of leadership did not mean a change of direction in French politics. Instead, the newly appointed Prime Minister continued in the footsteps of Mollet, extending the special powers given to the army in Algeria. The triumphalist and bellicose policies undertaken by Bourgès-Maunoury enjoyed popular support in France. Fanon refers explicitly to the jingoistic parade of the paratroopers in the Champs-Élysées on 14 July 1957, the day before the trial of the Algerian revolutionary Djamila Bouhired, who was accused of planting a bomb in a café in Algiers, concluded with the death penalty.

In November 1957, in response to a book written by Georges Arnaud and Jacques Vergès entitled Pour Djamila Bouhired, Fanon published 'À propos d'un plaidoyer' in El Moudjahid. Echoing Sartre's 'Le Colonialisme est un système', published in Les Temps modernes in March-April 1956, ${ }^{38}$ Fanon had already underscored in 'L'Algérie face aux tortionnaires français', published in El Moudjahid in September 1957, that colonial practice is premised on violence: 'La structure colonialiste repose sur la nécessité de torturer, de violer et de massacrer.' 39 Two months later, in 'À propos d'un plaidoyer', Fanon cautions against political expedience in the name of a narrow nationalism that sought to sacrifice the rights of 
the individual. He berates the French intellectuals and liberal left for their failure to uphold and safeguard the universality of the Republican tradition which was undermined by French colonialism. Bouhired emerges as an emblematic figure (much like Dreyfus), a victim whose individual rights were sacrificed in order to maintain the raison d'état. For Fanon, Bouhired epitomizes the violated Algerian: 'Il y a eu depuis de multiples Djamila Bouhired, torturées, violées et massacrées sur le territoire algérien. ${ }^{40}$ Bouhired is to be seen not as a convicted terrorist that French justice tried and sentenced to death, but as the subjugated colonized Algerian whose rights were denied by an oppressive colonialism. Fanon bemoans the failure of the Republican tradition: 'On mesure ici la réalité du retard historique de la conscience française. A la lutte pour le respect des libertés individuelles et les droits de l'Homme, si féconde il y a deux siècles, elle n'arrive pas à substituer la lutte pour les droits des peuples.' ${ }^{41}$ Fanon pours scorn on the French liberal left for their political apathy and for their misplaced patriotism. History, he contends, was being made without them: they could neither prevent Guy Mollet pandering to the ultras nor stop the deployment of troops to Algeria. He excoriates the French liberal left for instituting the emergency laws that gave the ultras special powers, for being able to do nothing in the face of the putsch of 13 May, for toeing the official line and for believing that France was fighting terrorism. ${ }^{42}$ In 'Les Intellectuels et les démocrates français devant la révolution algérienne', he dismisses the rhetoric used to justify the French government's action in Algeria as 'un patriotisme élémentaire mal structuré, hanté par le racisme, violent, totalitaire, somme toute fasciste' ${ }^{43}$ In 'Une Victoire', published in L'Express in March 1958 in response to Henri Alleg's La Question, Sartre echoes Fanon: ‘En 1958, à Alger, on torture régulièrement, systématiquement, tout le monde le sait, de M. Lacoste aux cultivateurs de l'Aveyron, personne n'en parle. ${ }^{44}$ Under the premiership of the socialist Guy Mollet and the liberal Bourgès-Maunoury, Sartre contends, the army was given full powers and the 'torturer-in-chief' replaced the police. ${ }^{45}$ Sartre and Fanon are as one in 
contending that France acted in complicity with a murderous colonialism in Algeria and that the liberal left colluded with fascism.

Under the aegis of Mollet, Fanon argues, the colonial administration instituted practices which sapped the universality of human rights and the principles upon which the constitution of government was founded in France: democracy was banished in colonial Algeria. ${ }^{46}$ The colonial administration gagged, tortured and murdered those who advocated these principles; Henri Alleg was incarcerated and tortured, while Maurice Audin paid the ultimate price for defending France's democratic principles. Fanon laments the fact that the French liberal left either collaborated with the colonial administration or sought refuge in silence. It is possible to establish a connection, as Fanon does in his comment about the violation of the human rights of the colonized people, between Bouhired, Alleg and Dreyfus. As a naturalized Frenchman, Alleg, like Dreyfus, was a victim whose rights as an individual were violated to maintain the raison d'état. Nonetheless, this figure was at the forefront of a neo-Dreyfusard movement represented by Jewish intellectuals. It seems that Fanon in 'La Minorité européenne d'Algérie' attempted to galvanize the voice of the neo-Dreyfusards in their fight against the colonial system and the raison d'état which was put in place by Mollet, Lacoste and Massu.

Unlike their French counterparts, Fanon maintains, the liberal left in Algeria stood resolutely against colonial fascism: Audin and Alleg emerged as proponents of a Dreyfusard tradition that very few intellectuals on the left in mainland France were willing to champion. Fanon presents their resistance against colonial fascism as a decolonization of France. ${ }^{47}$ Fanon also stresses the contribution of the European minority to the Algerian cause, contending that they provided not only ideological and organizational but also strategic and military support to the FLN. His intervention in 'La Minorité européenne d'Algérie' counteracted the psychological warfare conducted by the Fifth Bureau, which was attempting 
to fracture the movement of resistance. Referring to the Alleg case, Fanon writes:

Les Européennes et les Européens arrêtés et torturés par les services de police et les parachutistes français, par leur attitude sous les sévices, ont précisément montré la justesse de cette position du FLN. Pas un Français vraiment qui ait révélé aux policiers colonialistes des choses capitales pour la Révolution. Au contraire, les Européens arrêtés résistaient suffisamment pour permettre aux membres du réseau de disparaître. Le torturé européen s'est comporté comme un authentique militant dans le combat national pour l'indépendance. ${ }^{48}$

The European minority was ethnically diverse; religion complicated still further the issue of ethnicity and nationality. A sizeable proportion of the non-Muslim population was Jewish, who were granted political citizenship by the Crémieux laws. ${ }^{49}$ Colonial Algeria was essentially a racist state: Fanon maintains that 'on y trouve les différents mécanismes de la psychologie raciste' ${ }^{50}$ Some Jews identified with those who discriminated against them in the past, a paradoxical situation that Albert Memmi describes in his Portrait du colonisé, presenting the social structure of colonial Algeria in the form of a pyramid, with the colonizer at its apex and the colonized Algerians at its base..$^{51}$ It is true that the acculturated Jews enjoyed privileges, but these came at a price. In Le Monolinguisme de l'autre, Jacques Derrida bemoans the assimilationist policies which alienated Algerian Jews and led to the 'ossification' and 'necrotization' of their culture. ${ }^{52}$ Echoing Fanon's characterization of colonial Algeria as a compartmentalized society, he decries the impassable 'frontières de nuit' that consign the native Algerians to life in a state of apartheid. ${ }^{53}$ Like Fanon, he argues that assimilation was a sham: the privileges afforded to the Jews were taken from them when Vichy France abolished the Crémieux laws in October 1940. For Dreyfusards, like Alleg and Vidal-Naquet, Vichy collaboration and anti-Semitism undermined France's Republican principles, as would the Algerian war. Like Fanon, they considered their commitment to the Algerian cause to be a continuation of their resistance to fascism.

Fanon is adamant that the attitude of the Jews vis-à-vis the FLN and the revolution was not homogenous: those who sought shelter in the shadow of the colonial regime were in a minority; the majority of the Jews identified with the Algerians. ${ }^{54}$ Jewish tradesmen 
contributed financially and Jewish intellectuals demonstrated their support for the Algerian revolution. Alleg epitomizes the Dreyfusard who was willing to pay the ultimate price for the Algerian cause. 'Aujourd'hui encore', Fanon emphasizes, 'les avocats ou les médecins juifs qui partagent dans les camps ou en prison le sort de millions d'Algériens, attestent la réalité multiraciale de la Nation Algérienne. ${ }^{55}$ At the height of the Algerian war, these Jews realized that their 'attachement à une citoyenneté française artificielle est un leurre lorsque s'élabore à grands pas la jeune et puissante Nation algérienne moderne'. ${ }^{56}$

While criticizing the liberal left in the articles he wrote in 1957, two years later Fanon clearly solicits their political support. In 'La Minorité européenne d'Algérie' he cites two accounts: one by Yvon Bresson, a police officer who worked as an FLN agent; the other is written by Fanon's colleague Charles Geronimi. In line with Abane's political project to inaugurate a multicultural Algeria, Fanon seeks to establish the foundation for a rapprochement between the Algerians and the Europeans, as he suggests that the issue of nationality is up for grabs in post-independence Algeria, where Europeans, Jews, Berbers and Arabs will play a key role in an Algerian nation governed by democratic political institutions. In stark contrast with the opening chapter of Les Damnés de la terre, the tone of Fanon's 'La Minorité européenne d'Algérie' and his introduction to L'An $V$ de la révolution algérienne is conciliatory. His project is clear: 'Nous voulons une Algérie ouverte à tous, propice à tous les génies. ${ }^{57}$ Fanon's critique of the liberal left and his Marxist interpretation are tethered to the historical and political contexts of Algeria's decolonization and the PCF's position on the colonial question. Nevertheless, it is important to disentangle his critique of the liberal left in L’An V de la révolution algérienne from his Marxist exegesis in Les Damnés de la terre, which centres on the role played by the peasantry in the revolution.

\section{Between Fanon and Lyotard}


In 'Le Colonialisme est un système', Sartre analyzes the logic of colonialism as a manifestation of industrial capitalism that sought new markets for its products. ${ }^{58}$ JeanFrançois Lyotard expands on Sartre's critique; according to the figures he provides in $L a$ Guerre des Algériens, these markets in North Africa - and principally in Algeria - remained very weak, catering for a very small, predominantly European class. Private investment was directed towards financial services, not industry, thus keeping the economy in a preindustrial state. The colonial administration was against the modernization of the agricultural sector for fear that the fellahs would be promoted to the ranks of the European proletariat, thus undermining social stability. The maintenance of such stability, Lyotard argues, involved the expropriation of eighteen million Muslims in North Africa. ${ }^{59}$ Fanon unearths this history of expropriation, as he asserts that colonialism created an immiserated lumpenproletariat. ${ }^{60}$

Lyotard concurs with Fanon's assessment of the Algerian war as a peasant revolution. Seventy percent of Algerian agriculture was not economically viable. The insurgents were peasants: predominantly twenty years of age, they entered the armed struggle because they had nothing to lose; they were born in 1938, a year after the failure of the Blum-Viollette Bill; they were brought up in the dire conditions of the Second World War that saw the majority of the indigenous population in the grip of famine; and at the age of seven they experienced the Sétif massacre. ${ }^{61}$ Lyotard underscores that these insurgents' intransigence was determined by colonial violence, by their expropriation, by their immiseration and marginalization; the opening chapter of Les Damnés de la terre sets out the implications of this violence.

Out of touch and at odds with political reality, the conceptual language of the left was rendered obsolete by the colonial question. ${ }^{62}$ Lyotard rejects an abstract Marxist approach which conceived of the Algerian conflict as a 'class manifestation'; he refuses to consider the Mouvement national algérien (MNA) - a trade-unionist party which was set up by Messali Hadj as a rival to the FLN and which represented immigrant workers in France and peasants 
in Algeria - as a brand of Algerian Bolshevism. He is quick to point out that Messalism never represented 'l'avant-garde révolutionnaire du prolétariat algérien'. ${ }^{63}$ The 400000 Algerian workers in France were not an integral part of the French working class. Trotsky's notion of the permanent revolution was meaningless as far as they were concerned because these workers were kept segregated from their French counterparts by a whole culture - and by 350 kilometres of land and sea. ${ }^{64}$ There was ostensibly a cultural gap between the two peoples, a gap created by a history of brutal colonialism and exacerbated by a nationalistic conflict.

To fathom the politics that opened up such a gap, it is worth reconsidering from Fanon's perspective Thorez's view of colonial Algeria as a nation-in-formation. Whilst Thorez replaces the notion of race with that of nationality, thus suppressing the colonial issue, Fanon considers 'race' as a superstructure, constitutive of colonialism's Manichaean politics. In Les Damnés de la terre, elaborating further on this notion of 'race' as a superstructure, he writes: Ce monde compartimenté, ce monde coupé en deux est habité par des espèces différentes. L'originalité du contexte colonial, c'est que les réalités économiques, les inégalités, l'énorme différence des modes de vie, ne parviennent jamais à masquer les réalités humaines. Quand on aperçoit dans son immédiateté le contexte colonial, il est patent que ce qui morcelle le monde c'est d'abord le fait d'appartenir ou non à telle espèce, à telle race. Aux colonies, l'infrastructure économique est également une superstructure. La cause est conséquence: on est riche parce que blanc, on est blanc parce que riche. ${ }^{65}$

Class frontiers were consolidated by ethnic barriers to the extent that class attitudes were completely obfuscated or expressed in racial terms. ${ }^{66}$ Between those who exploited the means of agricultural production and those who were exploited - the European settlers and the dispossessed fellahs - there was a massive gap that was defined in racial terms. The same gap existed between the European workers and their Algerian counterparts. The Manichaean divide, which Fanon describes in Les Damnés de la terre, represents their compartmentalized existence: a police cordon segregated the European workers that lived in Bad-el-Oued from the Algerian workers in the Casbah. The European and Algerian workers never constituted a community of shared political interests. ${ }^{67}$ Even when they were exploited in the same way as 
the Algerian proletariat, the European workers never identified with the latter as a class. Identification was expressed in cultural and ethnic terms. The French proletariat never considered that its class interests converged with the class interests of the oppressed/colonized peoples.

According to both Fanon and Lyotard, the Algerian conflict was exacerbated by two types of nationalisms which were at loggerheads: the one was colonialist; the other marshalled the dispossessed Algerian peasantry in its anti-colonial struggle. It is true, as Nghe suggests, that the urban working class and the bourgeois elite played a key role in mobilizing the nationalist movement; it is also true that historical and political factors complicated the Marxist notion of class struggle in colonial Algeria. Lyotard shows how nationalism - be it anticolonial or fascistic - overshadowed such a notion. Although it originated from a tradeunionist movement of working-class immigrants in France, the MTLD, founded in 1946 following the dissolution of the PPA, nevertheless attempted to disavow its class specificity and present itself as the 'parti de masse'. ${ }^{68}$ The leaders of the MTLD - the national bourgeoisie to whom Nghe assigns a revolutionary pedagogy - were adamant that there were no social/class distinctions and therefore no class antagonisms in Algeria. Oblivious to the specificities of class, the party appeared as a monolithic organization without a doctrine and could not conceive of a political programme to tackle the problems of the dispossessed masses, namely the peasantry. On the other hand, astutely attentive to the diversity of social/class interests, the FLN promoted an ideology that permeated every aspect of Algerian society, rural and urban alike, working to incorporate the interests of the petty bourgeoisie, the proletariat, the lumpenproletariat and the peasantry in the national struggle. It was the only party that managed to mobilize militants from the MTLD, the UDMA and the Oulemas to join the armed struggle. Its centralism was engendered by the struggle. In 1955, the party was no longer controlled by the masses and the bourgeois elements which joined the organization 
ended up exacerbating its centralist tendency. As a unique and centralized party, the FLN established itself in rural and urban areas and managed henceforth to have complete control over the totality of the Algerian population. Whilst rallying behind the FLN revolutionary movement which represented the masses, Fanon seems to target its centralist and bourgeois propensities in his critique of the pitfalls of nationalism, maintaining that the expropriated peasantry was the only revolutionary class.

The FLN could not be 'l'incarnation du prolétariat algérien' but was a sort of union sacrée of workers, peasants and petty bourgeois. ${ }^{69}$ The 'proletariat', 'middle class', 'bourgeoisie' and the 'peasantry' are not abstract entities but are determined by the specificities of colonial history and politics. The peasantry was specifically Algerian, a class that constituted the social basis of the nationalist movement: the revolution was nothing but the expression of the expropriated and uprooted Algerian peasantry. It was not an abstract definition of the peasantry that brought about 'class suture' in Algeria; it was the history of colonial exploitation that shaped this class solidarity and gave rise to national consciousness. In his critique of Fanon, Nghe, eliding the racialized terms of the colonial problematic and the nationalistic discourse which obscured class antagonism, overlooks that this history was defined not in terms of class - i.e. the proletariat or peasantry - but in terms of ethnicity and nationality.

Chiming with Fanon's critique of the liberal left, Lyotard's criticisms of Marxist Leninism are worth reviewing from the historical perspective of the colonial consensus. In $\mathrm{La}$ Guerre des Algériens, he raises three interlinked issues: first, class and nationalist antagonisms in colonial Algeria; secondly, the power vacuum created by the Algerian war; and thirdly, the French communists' stance with regards to class solidarity and decolonization. The Battle of Algiers changed the internal dynamics of French politics; it brought about an unholy alliance between left and extreme right, obscuring class differences. How did the left 
come to support the ultras and how did the FLN come to yoke together different, even contradictory, class positions in its anticolonial struggle? Marxist rhetoric was anachronistic as it could not conceive of the hidden contradictions inherent within the colonial society. The army, bent on restoring its pride in Algeria after its humiliating defeat in Indochina and the Suez crisis, instituted a raison d'état undercutting the Republican tradition and sacrificing individual freedom. It was not Lacoste but the ultras that held power in Algiers. By the same token, it was not Paris but Algiers which determined the political agenda of mainland France. Lyotard points out that in the countryside there was an FLN organization and in the cities there was a colonial administration controlled by the ultras, but in Paris there was a political vacuum. After pelting Mollet with tomatoes, the ultras dominated French politics: they imposed their fascistic slogans on France and oppressed its political atmosphere. Like Sartre and Fanon, Lyotard denounces the collusion of the French left (namely the PCF and the SFIO) with colonial fascism that threatened to undermine France's Republican principles and political institutions.

It is important to bear in mind that Fanon wrote 'L'Algérie face aux tortionnaires français', ‘À propos d'un plaidoyer', 'Les Intellectuels et les démocrates français devant la révolution algérienne' and 'La Minorité européenne d'Algérie' in order to seek the support of the liberal left and to denounce the raison d'état which denied the rights of Bouhired and Alleg. Fanon clearly links the theme of violence with the raison d'état; the reference to Guy Mollet in Les Damnés de la terre is significant in this respect. The Manichean economy which gave rise to such violence is not a confrontation of rational points of view; it is purely the expression of raison d'état maintained with the help of the army and the police. This violence was blind and unthinking, but emerged from the 'mad darkness' of colonialism: it operated within a consensus which, in order to uphold France's colonial interests, renounced one of the cornerstones of the Republican tradition. Just like the Dreyfus Affair, the Algerian war 
polarized French society - and the divisions were not along class or partisan lines. It did not set the liberal left against the clergy and the ultra-nationalists, those who defended the inalienable rights of the individual (the proponents of the Ligue des droits de l'homme) and those who put the interests of the state above these rights. The Algerian war confused these demarcation lines: it is one of the ironies of history that Guy Mollet, a socialist and member of the Ligue des droits de l'homme, with the help of the communists, presided over (and covered up for) the systematic practice of torture; the liberals of Témoignage chrétien - those who recruited Fanon to the Algerian cause - emerged as neo-Dreyfusards resisting the raison d'état instituted by the left. ${ }^{70}$

As we have seen, the political direction taken by Thorez in the 1930s impinged on the history of the PCF as the party moved away from its former internationalist agenda and espoused a narrow nationalism in the defence of the Republic against the threat of fascism. The class-against-class strategy in Marxist Leninism was effectively held in check by nationalism which came to obfuscate racial and colonial antagonism. The PCF's colonial policies in the 1930s, Irwin Wall rightly argues, 'came back to haunt it in the 1950s when the party could not formulate an adequate response to the Algerian war'. ${ }^{71}$ Thorez's anti-fascist front paradoxically determined the colonial consensus which, at the height of the Algerian crisis, brought together left and right, communists and ultras in a baneful coalition, giving rise to fascism in Algeria. This fascism brought down the Fourth Republic in the putsch of 13 May 1958. Lyotard denounces the PCF for being notoriously weak and spineless - as 'mol' as Guy Mollet $^{72}$ - and for colluding with the ultras. He is quick to point out that the liberal left turned a blind eye to the heavy-handed pacification led by the army and that the SFIO and the PCF participated indirectly and directly in this repression. In this respect, the correlation which Césaire establishes between colonialism and fascism in his Discours sur le colonialisme is all the more poignant. In his famous Lettre à Maurice Thorez, Césaire tends his resignation after 
the PCF supported the Mollet government's Special Powers Act in 1956, exploding the contradictions in its stance on the colonial question. If the PCF resisted the rise of fascism in the 1930s, paradoxically it found itself in cahoots with the fascist ultras in the Algerian conflict. In L'An V de la révolution algérienne and his journalistic writings, Fanon decries such complicity; in Les Damnés de la terre he revises the conceptual language of the left which was anachronistically at odds with colonial reality.

In sum, the vestiges of subjectivism in Les Damnés de la terre are inherited from existential phenomenology and expressed in Marxist terms in Peau noire, masques blancs. Fanon broaches the subject of Marxism explicitly in his rebuttal of Sartre's dialectical schema for objectifying the subjectivity of the black and implicitly in his critique of the dichotomous language of racism that seals the black in their blackness and the white in their whiteness. In Les Damnés de la terre, he enlarges on this subject contending that the specificities of race and ethnicity must be taken into account in the dialectics governing the Manichaean economy of colonial society. Lyotard adds to the debate initiated by Fanon, excoriating Marxist Leninism for overlooking the significance of nationalism. However, Marxist theory must not be conflated with Marxist Leninism and the politics of the party it subtends, namely the PCF, just as Marx must not be confused with Thorez. I have chosen to read Fanon and Lyotard in tandem to show that whereas Marx, according to Fanon, suppresses the notion of 'race' and the colonial question in a grand narrative on class struggle, Thorez supplants the notion of 'race' with 'nation' and suppresses the colonial issue by deploying nationalism as a political device in his rhetoric of nation-in-formation.

It is worth reiterating that Fanon's take on Marxism is determined by the context of decolonization and by the PCF's politics on the colonial issue and that his Marxist analysis is intertwined with his critique of the liberal left. The insurgent Fanon is the product of the historical and political circumstances that gave rise to the raison d'état which forced him to 
join the FLN's 'délégation extérieure', exiled in Tunis. His radicalism stems, then, from the specificities of anticolonial struggle. In his El Moudjahid critique of the colonial consensus, he ostensibly targets the French liberal left who colluded with the ultras; in Les Damnés de la terre, he cautions against the pitfalls of nationalism. The brand of nationalism he advocates is internationalist: it is at a variance with Thorez's nationalism; it follows in the footsteps of the Internationale, but the dubious history implicating the PCF in maintaining the colonial consensus led him to rethink Marxist Leninism as a viable alternative to the colonial status quo.

\section{Notes}

1. See David Macey, Frantz Fanon: A Biography, $2^{\text {nd }}$ ed. (London: Verso, 2012), pp. 21-2.

2. See Hannah Arendt, On Violence (London: The Penguin Press, 1970), and Lewis Coser, 'Fanon and Debray: Theorists of the Third World', in Beyond the New Left, ed. by Irving Howe (New York: The McCall Publishing Company, 1970), pp. 120-34.

3. Gilbert Comte, 'Un Mein Kampf de la décolonisation', La Nation française, 21 March 1962, cited in Macey, Frantz Fanon, p. 21.

4. See Dennis Forsythe, 'Fanon: The Marx of the Third World', Phylon, 34:2 (1973), 160-70 (p. 165).

5. Frantz Fanon, Peau noire, masques blancs (Paris: Seuil, 1952), p. 8.

6. Frantz Fanon, Les Damnés de la terre (1961; Paris: Gallimard, 1991), p. 70.

7. Ibid., p. 146.

8. Nguyen Nghe, 'Frantz Fanon et les problèmes de l'indépendance', La Pensée, 107 (February 1963), 23-36 (p. 27).

9. Ibid., p. 28.

10. Ibid., p. 29. 
11. Ibid., p. 30 .

12. Ibid., p. 31.

13. Ibid., pp. 31-2.

14. Ibid., p. 32.

15. Ibid., p. 32. Like Nghe, Renata Zahar hails the proletarianization of the colonised as a coming-into-consciousness and suggests that Fanon's generalisation 'leaves open the question whether revolutionary processes cannot after all be initiated among the proletariat with its much higher degree of organization'; see R. Zahar, Frantz Fanon: Colonialism and Alienation (New York and London: Monthly Review Press, 1974), p. 105. She also argues that what Fanon offers is 'a phenomenological description of neocolonialism which is in general correct but which is restricted to the conditions in the former colonies'; moreover, this description is characterised by a lack of 'any analysis of international relations of dependency nor of the background and motives of modern imperialist policies' (p. 101).

16. Nghe, 'Frantz Fanon et les problèmes de l'indépendance', p. 33.

17. See Irwin M. Wall, 'Front Populaire, Front National: The Colonial Example', International Labor and Working-Class History, 30 (1986), 32-43, who notes: 'When it became apparent in August 1936 that the Blum government coalition's reformist impulse was spent and its anti-fascist resolve showed signs of flagging under the impact of the Spanish Civil War, the PCF proposed the Front français. The party proposed extending the electoral alliance to all those on the right willing to rally around an anti-German standard' (p. 33). 18. Maurice Thorez, 'La Nation algérienne en formation', in Textes choisis sur l'Algérie (Paris: Parti communiste français, 1962), pp. 16-24. Thorez's speech is cited in Jakob Moneta, 'Le Peuple algérien uni autour de la France', in La Politique du Parti communiste français dans la question coloniale, 1920-1963 (Paris: Maspero, 1971), pp. 134-38.

19. See Azzedine Haddour, Colonial Myths: History and Narrative (Manchester: Manchester 
University Press, 2000), pp. 24-9.

20. Gabriel Audisio, Sel de la mer (Paris: Gallimard, 1936), pp. 118-21.

21. Ibid., pp. 107, 113.

22. Albert Camus, 'La Culture indigène, la nouvelle culture méditerranénne', in Essais, ed. by Roger Quilliot and Louis Faucon (Paris: Gallimard, 1965), pp. 1321-7 (p. 1324).

23. Thorez, 'La Nation algérienne en formation', pp. 20-1.

24. Thorez, 'La France du Front populaire', in Textes choisis sur l'Algérie, pp. 11-24 (p. 12). 25. Ibid., p. 12.

26. Thorez, 'La Nation algérienne en formation', p. 22.

27. Ibid., p. 19.

28. Tony Smith, 'The French Colonial Consensus and People's War, 1946-58', Journal of Contemporary History, 9:4 (1974), 217-47.

29. Ibid., p. 229.

30. Ibid., p. 229.

31. Ibid., p. 220.

32. On his visit to Algiers on 6 February 1956, Guy Mollet was met by an angry mob, led by the ultras, who pelted him with rotten tomatoes.

33. Frantz Fanon, 'Lettre au Ministre Résident', in Pour la révolution africaine (Paris:

Maspero, 1969), pp. 50-3.

34. Frantz Fanon, 'La Minorité européenne d'Algérie', in L'An V de la révolution algérienne (Paris: La Découverte, 2001), pp. 136-54 (p. 137).

35. Ibid., p. 138.

36. Ibid., p. 140.

37. Fanon, 'Les Intellectuels et les démocrates français devant la révolution algérienne', in Pour la révolution africaine, pp. 72-86 (pp. 74-5). 
38. See Jean-Paul Sartre, 'Le Colonialisme est un système', in Situations V (Paris: Gallimard, 1964), pp. 25-48.

39. Fanon, 'L'Algérie face aux tortionnaires français', in Pour la révolution africaine, pp. 608 (p. 67).

40. Fanon, 'À propos d'un plaidoyer', in Pour la révolution africaine, pp. 69-71 (p. 70).

41. Ibid., p. 70.

42. Fanon, 'La Minorité européenne d'Algérie', p. 139.

43. Fanon, 'Les Intellectuels et les démocrates français devant la révolution algérienne', p. 75.

44. Jean-Paul Sartre, 'Une Victoire', in Situations V, pp. 72-88 (p. 72). Criticizing the Mollet government for instituting torture, Sartre goes on to add: 'Alleg nu, tremblant de froid, attaché à une planche encore noire et gluante des vomissements anciens, réduit tous ces manèges à leur pitoyable vérité : ce sont des comédies jouées par des imbéciles. Comédie, la violence fasciste de leurs propos, le serment d'aller "foutre en l'air la République"' (p. 76).

45. Ibid., p. 80 .

46. Fanon, 'La Minorité européenne d'Algérie', p. 139.

47. Ibid., p. 139.

48. Ibid., p. 141.

49. Ibid., p. 143.

50. Ibid., p. 144.

51. See Albert Memmi, Portrait du colonisé (Paris: Payot, 1973), pp. 17-18.

52. Jacques Derrida, Le Monolinguisme de l'autre (Paris: Galilée, 1996), p. 89.

53. Ibid., p. 66.

54. Fanon, 'La Minorité européenne d'Algérie', p. 145.

55. Ibid., p. 147.

56. Ibid., p. 147. 
57. Fanon, 'Sociologie d'une révolution', in L'An V de la révolution algérienne, pp. 5-15 (p.

$15)$.

58. Sartre, 'Le Colonialisme est un système', pp. 28-9.

59. Jean-François Lyotard, La Guerre des Algériens (Paris: Galilée, 1989), p. 44.

60. Fanon, Les Damnés de la terre, pp. 167-8.

61. Lyotard, La Guerre des Algériens, p. 93.

62. Ibid., p. 90.

63. Ibid., pp. 102-3.

64. Ibid., p. 103.

65. Fanon, Les Damnés de la terre, p. 70.

66. Like Fanon, Lyotard contends that it was because of their ethnicity, not because of their class position, that the Algerians were completely crushed: 'C'est donc la totalité des musulmans qui est saisie et broyée par la poigne des colons: la société maghrébine est une société totalitaire, où l'exploitation suppose la terreur. Et comme les frontières de classes sont à peu prés exactement recouvertes par les frontières "ethniques", une conscience de classes est impossible: c'est autant comme Algérien ou Tunisien que comme ouvrier ou paysan que l’homme est écrasé. Le flic qui matraque ou qui torture est européen, le patron ou le contremaître est européen, l'officier est européen, le professeur est européen, le mépris est européen et la misère "arabe". La lutte se situe d'emblée sur le plan national, elle cherche spontanément à supprimer l'appareil terroriste comme immédiate de l'oppression, et l'indépendance, c'est-à-dire cette suppression, apparaît à tous comme le contraire de l'exploitation' (La Guerre des Algériens, pp. 45-6).

67. Ibid., p. 106.

68. Ibid., p. 70.

69. Ibid., p. 103. 
70. As Michel Winock notes, 'pendant la guerre d'Algérie, au moment du grand débat sur la torture, un néo-dreyfusisme entraîna de nouveau nombre d'intellectuels contre la raison d'État'; see M. Winock, 'L'Affaire Dreyfus comme mythe fondateur', in La France politique (Paris: Seuil, 2003), pp. 151-65 (p. 164).

71. Wall, 'Front Populaire, Front National', p. 35.

72. Lyotard, La Guerre des Algériens, p. 100. 